TECTONICS, VOL. 12, NO. 5, PAGES 1131-1139, OCTOBER 1993

\section{THE MALA ŴI EARTHQUAKE OF MARCH 10, 1989: DEEP FAULTING WITHIN THE EAST AFRICAN RIFT SYSTEM}

\author{
James Jackson \\ Bullard Laboratories \\ Cambridge University \\ Cambridge, England \\ Tom Blenkinsop \\ Department of Geology \\ University of Zimbabwe \\ Harare, Zimbabwe
}

\begin{abstract}
Since 1964 there have been six earthquakes of $M_{\boldsymbol{w}} \geq 5.5$ in east Africa whose centroid depths have been demonstrated to be in the range of $25-40 \mathrm{~km}$. These depths are significantly greater than the $5-$ to $15-\mathrm{km}$ range typical of most other regions of continental extension. The March 10, 1989 earthquake $\left(M_{w} 6.1\right)$ in Malawi is the first such deep event to have occurred within the main topographic expression of the late Cenozoic east African rift system. Its focal mechanism and depth $(32 \pm 5 \mathrm{~km})$ allow it to be plausibly associated with slip on a deep part of a major normal fault zone bounding the Malawii rift. We cannot determine whether the earthquake occurred in the crust or mantle or whether the postulated fault zone exists as a continuous seismogenic surface from the upper crust to depths of $\sim 30 \mathrm{~km}$ : it is possible that the fault zone exists as an aseismic shear zone in the lower crust. In the Malawi rift the width of the half graben (up to $50 \mathrm{~km}$ ), the effective elastic thickness of the lithosphere $(\sim 35 \mathrm{~km})$, and probably the largest fault segment lengths $(>50 \mathrm{~km})$ are greater than is typical in rifts outside Africa. We suggest that these features and the greater earthquake depths are all related to the likelihood that the upper part of the lithosphere is colder and stronger than is typical elsewhere. These observations are consistent with earlier suggestions that normal faulting and significant strength can exist throughout the bulk of the crustal thickness. If this is the case, wide half graben can form without requiring shear strengths on the bounding faults to be greater than 1-10 $\mathrm{MPa}$ (10-100 bars), which is the typical level of stress drop observed in earthquakes.
\end{abstract}

\section{INTRODUCTION}

Earthquake focal depths determined by teleseismic arrival times alone are notoriously inaccurate. An important advance of the $1980 \mathrm{~s}$, and one with major impact on views of lithosphere rheology, was the use of teleseismic waveforms to constrain the depth of the earthquake centroid, which is the conceptual point source representing the weighted center of the finite fault plane that radiates seismic energy. The centroid depths of most

Copyright 1993 by the American Geophysical Union.

Paper number 93TC01064.

0278-7407/93/93TC-01064\$10.00 continental earthquakes of $m_{b} \geq 5.5$ occur in the upper half of the crust, typically in the depth range of $5-15 \mathrm{~km}$ [see Chen and Molnar, 1983]. This range is also typical of earthquake centroid depths in regions of active continental extension outside Africa [Jackson and White, 1989]. Shudofsky [1985], using a combination of Rayleigh wave spectra and $P$ waveform analysis, pointed out that some earthquakes in east Africa had unusually deep centroids of 25-30 km. Body waves are able to determine centroid depth more accurately than surface waves, and a combination of $P$ and $S H$ waveforms is superior to $P$ waveforms alone as the trade-off between the far-field source time function and depth is reduced. Of the earthquakes in the depth range of $25-30 \mathrm{~km}$ reported by Shudofsky [1985], five had centroid depths that were constrained to some extent by his analysis of their $P$ waveforms. Using both $P$ and $S H$ waveforms, Wagner and Langston [1988, 1989] subsequently showed that two of these five were actually shallow (4 and $10 \mathrm{~km}$ ) but confirmed that another of the earthquakes really was at $\sim 28 \mathrm{~km}$. Yarwood and Doser [1988] confirmed still another at $\sim 28 \mathrm{~km}$. Grimison and Chen [1988] also reported two earthquakes at a depth of $\sim 40 \mathrm{~km}$ on the east coast of Africa. In this paper we show that another earthquake in Malawi had a centroid depth of $\sim 30 \mathrm{~km}$. Table 1 and Figure 1 show the earthquakes in east Africa whose centroid depths have been determined by body wave analysis and contain six with depths in the range of $25-40 \mathrm{~km}$, of which five are constrained by $P$ and $S H$ and one by $P$ waveforms alone. Those with both $P$ and $S H$ control have probable depth errors of about $\pm 5 \mathrm{~km}$.

The earthquakes in Table 1 fall into two groups: those shallower than $17 \mathrm{~km}$ and those deeper than $25 \mathrm{~km}$. In fact, the best constrained of the shallow group all have centroids shallower than $14 \mathrm{~km}$. The paucity of earthquakes between 15 and $25 \mathrm{~km}$ is a pattern that is familiar elsewhere [e.g., Chen and Molnar, 1983] and is often used to support the view that seismogenic normal faults in the upper crust do not penetrate significantly into the lower crust, which deforms instead by aseismic slip on shear zones or by flow [e.g., Jackson and White, 1989].

Opinion is divided as to whether the deeper earthquakes in east Africa represent faulting in the lower crust or uppermost mantle. Shudofsky et al. [1987] argue that they occur in the lowest part of the crust in lithosphere that is old, cold, and unusually strong. Nyblade et al. [1992] support this view, claiming that the uncertainties in measured surface heat flow and probable crustal temperature profiles allow this interpretation. On the other hand, Yarwood and Doser [1988] emphasize the possibility that the earthquakes occur in the uppermost mantle. Our own opinion is that the crustal thickness in these regions is not known with sufficient accuracy to be sure whether centroid depths in the range of $25-35 \mathrm{~km}$ lie in the crust or in the mantle. Nor do we claim to know whether the 1989 Malawi earthquake, the subject of this paper, with its centroid at $\sim 30 \mathrm{~km}$, occurred in the crust or mantle. We are concerned here with the probable consequences of these unusually deep centroids and their association with other phenomena. The following points are relevant to this issue:

1. Most earthquakes that occur in the continental upper mantle elsewhere are in regions of shortening and low 


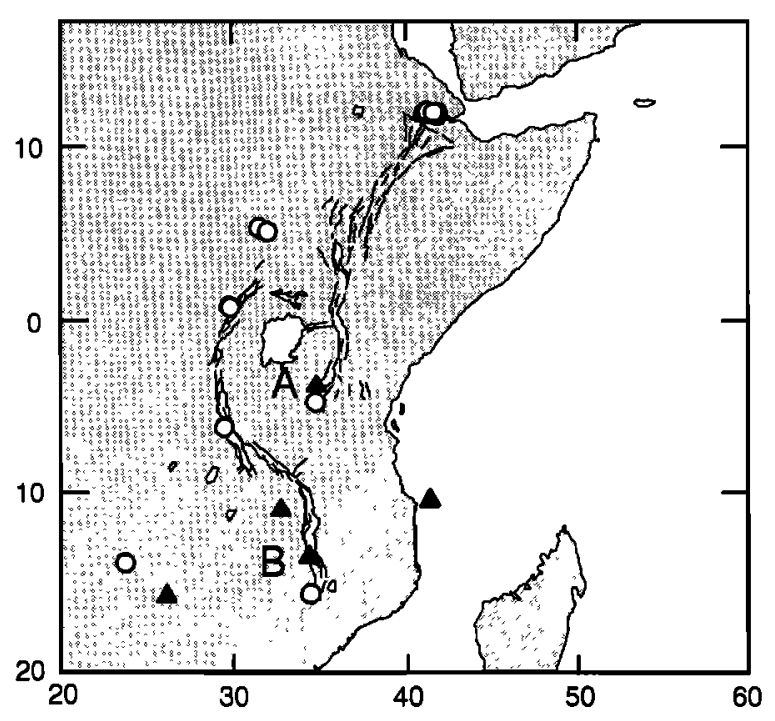

Fig. 1. Epicenters of earthquakes in east Africa whose centroid depths are constrained by body waveforms (Table 1). Circles represent earthquakes with depths of $<18 \mathrm{~km}$ and triangles, those with depths of $>24 \mathrm{~km}$. The main faults of the eastern and western rift systems are shown. The Tanzanian strike-slip event of May 7, 1964, is marked A. The March 10, 1989, earthquake in Malawi is marked B.

expected geothermal gradient [Chen and Molnar, 1983]

2. Simple mechanical arguments and the probable relative strengths of crustal and mantle rocks suggest not only that earthquakes in the continental mantle should be more likely where the mantle is colder but also that if the lowermost crust is cold enough to deform in earthquakes, then the uppermost mantle beneath it will also be cold enough to do the same [e.g., Brace and Kohlstedt, 1980; Chen and Molnar, 1983].

3. Thus the earthquakes at $25-$ to $40-\mathrm{km}$ depth in east Africa probably occur in rocks that are colder and stronger than those at similar depths in other rifts, where earthquakes typically occur no deeper than $\sim 15 \mathrm{~km}$.

4. The deeper earthquakes in Table 1 are of a size (up to $M_{w} 6.2-6.5$ ) such that the fault surfaces which slipped have dimensions of at least $10-15 \mathrm{~km}$ (we estimate the fault size in the 1989 Malawi earthquake later). Faulting is therefore likely to extend $\sim 5 \mathbf{~ k m}$ vertically above and below the centroid depth.

5. It is quite possible that rupture in these deeper earthquakes involves slip in both the lowermost crust and uppermost mantle. Just as the high strain rate during seismic slip in the upper crust is thought to allow the rupture in large earthquakes to propagate downward into the uppermost part of the normally aseismic lower crust [e.g., Scholz, 1988], there is no reason why rupture in the uppermost mantle should not also propagate upward into the lower crust, particularly if the lower crust is colder and stronger than normal.

We emphasize that it is not our intention in this paper to enter the debate about whether the centroids of these deeper earthquakes are located in the crust or in the mantle. For our purposes, their significance is that they indicate that the uppermost lithosphere is likely to be colder and stronger than elsewhere. Here we are interested in the possible consequences and manifestations of this strength, such as the effective elastic thickness of the lithosphere and the size of the geological structures observed at the surface. In cold, strong crust we can envisage fault zones extending from the surface into the uppermost mantle, although they might exist as aseismic shear zones in the lower crust. Is there any evidence for such throughgoing faults? Shudofsky et al. [1987] observed that the deeper events shown in Figure 1 (except for the 1989 Malawi earthquake reported here) all occurred outside the part of the rift system that is best expressed geologically and topographically. It is therefore difficult to associate them with particular surface faults, although all except the May 7, 1964 event (marked A in Figure 1), which was strike-slip, involved normal faulting with the strike of one nodal plane similar to that of the known Cenozoic faults in their epicentral regions. The 1989 Malawii earthquake (marked B in Figure 1) occurred within the rift occupied by Lake Malawi (Nyasa) itself, the shallow structure of which has been investigated by seismic reflection profiling [Ebinger et al., 1984, 1987; Scholz, 1987; Specht and Rosendahl, 1989; Flannery and Rosendahl, 1990]. It therefore offers an opportunity to compare the seismogenic faulting at depth with the known surface geology and structure.

\section{THE 1989 MALAŴI EARTHQUAKE}

We studied the source parameters of the 1989 Malawi earthquake using the algorithm of McCaffrey and Abers [1988], which inverts $P$ and $S H$ waveform data to obtain the strike, dip, rake, centroid depth, seismic moment, and source time function. The method and approach are described in detail elsewhere [e.g., Nábèlek, 1984; McCaffrey and Nábĕlek, 1987; Taymaz et al., 1991] and are now too routine to justify repetition here. Both observed and synthetic long-period $P$ and $S H$ seismograms for the final inversion result are shown in Figure 2. The source parameters we obtain are compared with those of the Harvard centroid moment tensor (CMT) solution [Dziewonski et al., 1990] in Table 2. Our centroid depth of $32 \mathrm{~km}$ is greater than that of the Harvard CMT solution (fixed at $15 \mathrm{~km}$ ) and is confirmed by tests shown in Figure 3: when constrained to a shallow depth, the inversion routine is unable to reproduce the broad, long-period pulses (characteristic of a deeper earthquake), which it attempts to fit with a longer and more jagged source time function. The resulting fit of observed and synthetic waveforms is noticeably worse at shallow depths than at a depth of $32 \mathrm{~km}$. The fit is inferior to that at $32 \mathrm{~km}$ if the depth is changed by more than $\pm 5 \mathrm{~km}$, which is a reasonable estimate of the error. The mechanism of the earthquake was almost pure normal faulting, with both nodal planes striking roughly NNW-SSE. The dip of the nodal plane dipping west is well constrained to $34 \pm 5^{\circ}$ (Figure 3).

The inversion for source parameters in Figure 3 assumed that the $P$ velocity in the earthquake source region was a typical lower crustal value of $6.8 \mathrm{~km} \mathrm{~s}^{-1}$ (see Figure 3). The fit of observed and synthetic waveforms is not significantly different if the velocity in the source 
TABLE 1. Earthquakes Whose Centroid Depths Are Constrained by Body Wave Modelling

\begin{tabular}{|c|c|c|c|c|c|c|c|}
\hline Date & Time & $\begin{array}{c}\text { Latitude, } \\
\text { deg }\end{array}$ & $\begin{array}{c}\text { Longitude, } \\
\text { deg }\end{array}$ & $\begin{array}{c}\text { Depth, } \\
\text { km }\end{array}$ & $\overline{M_{w}}$ & $\begin{array}{c}\text { Rake, } \\
\text { deg }\end{array}$ & Reference \\
\hline May 7, 1964 & 0545 & -3.90 & 34.92 & 28 & 6.5 & -5 & Yarwood and Doser [1988] \\
\hline March 20, 1966 & 0142 & 0.81 & 29.90 & 10 & 6.6 & -82 & Wagner and Langston [1988] \\
\hline May 6,1966 & 0236 & -15.72 & 34.59 & $17^{*}$ & 5.1 & -90 & Shudofsky [1985] (P) \\
\hline May 17,1966 & 0703 & 0.76 & 29.95 & 7 & 5.6 & -133 & Shudofsky [1985] (P) \\
\hline May 15,1968 & 0751 & -15.91 & 26.16 & 28 & 5.6 & -97 & Wagner and Langston [1988] \\
\hline Dec. 2, 1968 & 0233 & -14.01 & 23.82 & 6 & 5.7 & -95 & Wagner and Langston [1988] \\
\hline March 29, 1969 & 0915 & 11.91 & 41.21 & 6 & 6.2 & -16 & Kebede et al. [1989] \\
\hline March 29, 1969 & 1104 & 11.92 & 41.36 & 5 & 5.8 & +5 & Kebede et al. [1989] \\
\hline April 5, 1969 & 0218 & 12.00 & 41.35 & 4 & 6.1 & -45 & Wagner and Langston [1988] \\
\hline April 6, 1969 & 1651 & 11.99 & 41.40 & 5 & 5.7 & +30 & Kebede et al. [1989] \\
\hline Sept. 29,1969 & 2003 & -33.09 & 19.52 & 4 & 6.3 & -1 & Wagner and Langston [1988] \\
\hline April 4, 1975 & 1741 & -21.24 & 45.13 & 11 & 5.6 & +40 & Shudofsky [1985] (P) \\
\hline July 1,1976 & 1124 & -29.51 & 25.17 & 6 & 6.6 & -39 & Shudofsky [1985] (P) \\
\hline Sept. 19,1976 & 1459 & -11.08 & 32.84 & 25 & 5.5 & -52 & Shudofsky [1985] (P) \\
\hline July 6,1977 & 0848 & -6.26 & 29.59 & $14^{*}$ & 5.3 & -77 & Shudofsky [1985] (P) \\
\hline Dec. 15,1977 & 2320 & -4.80 & 34.92 & $12^{*}$ & 5.4 & -129 & Shudofsky [1985] (P) \\
\hline May 14,1985 & 1324 & -10.59 & 41.37 & $40 \dagger$ & 6.2 & -90 & Grimison and Chen [1988] \\
\hline May 14,1985 & 1811 & -10.49 & 41.43 & $40 t$ & 6.4 & -90 & Grimison and Chen [1988] \\
\hline March 10, 1989 & 2149 & -13.74 & 34.41 & 33 & 6.1 & -81 & This paper \\
\hline Aug. 20, 1989 & 1116 & 11.77 & 41.94 & 5 & 6.4 & -76 & Braunmiller and Nabalek [1990] \\
\hline Aug. 20, 1989 & 1117 & 11.92 & 41.96 & 4 & 6.2 & -73 & Braunmiller and Nabalek [1990] \\
\hline Aug. 20, 1989 & 1925 & 11.90 & 41.82 & 6 & 6.1 & -85 & Braunmiller and Nabalek [1990] \\
\hline Aug. 21, 1989 & 0109 & 11.87 & 41.87 & 6 & 6.4 & -95 & Braunmiller and Nabalek [1990] \\
\hline Aug. 21, 1989 & 0503 & 11.94 & 41.77 & 7 & 6.0 & -87 & Braunmiller and Nabalek [1990] \\
\hline May 20,1990 & 0222 & 5.12 & 32.15 & 13 & 7.2 & 14 & Gaulon et al. [1992] \\
\hline May 24, 1990 & 1934 & 5.28 & 31.83 & 14 & 6.3 & -59 & Gaulon et al. [1992] \\
\hline July 9,1990 & 0122 & 5.40 & 31.65 & 11 & 6.5 & -62 & Gaulon et al. [1992] \\
\hline
\end{tabular}

The (P) after Shudofsky's citation emphasizes that these events were constrained by $\mathrm{P}$ waves only; both $\mathrm{P}$ and $\mathrm{SH}$ were used for the others.

*The solution is of poor quality.

†Double shocks at $\sim 40 \mathrm{~km}$ and $\sim 20 \mathrm{~km}$ [Grimison and Chen, 1988].

region is changed to a mantle velocity of $8.1 \mathrm{~km} \mathrm{~s}^{-1}$, nor is the solution itself significantly changed: the strike, dip, and rake all change by less than $2^{\circ}$; the depth changes to $35 \mathrm{~km}$; and the moment changes to $3.0 \times 10^{18} \mathrm{~N} \mathrm{~m}$. The orientation and depth of the earthquake source determined by the inversion routine are therefore not sensitive to whether the centroid is located in the crust or the mantle.

The earthquake occurred at the southern end of Lake Malaŵi (Nyasa), in a region whose geological structure is that of a large homocline dipping east toward a system of major west dipping normal faults that bound the eastern edge of the lake (see Figure 4) [Ebinger et al., 1987; Scholz, 1987; Chapola and Kaphwiyo, 1992]. In the region of the epicentre the homocline is disturbed by a monocline downthrown to the east. The closest seismic station used in the epicentral determination by the International Seismological Centre (ISC), Edinburgh, is $300 \mathrm{~km}$ away, and only two stations were closer than $900 \mathrm{~km}$. This epicenter $\left(13.74^{\circ} \mathrm{S}, 34.41^{\circ} \mathrm{E}\right)$ could be wrong by up to $\sim 20 \mathrm{~km}$ [see, e.g., Taymaz et al., 1991], but it is nonetheless consistent with the damage effects [Gupta, 1992], which were quite localized, as expected for an earthquake of this moderate size. If we adopt the ISC epicenter and project a nodal plane dipping $34^{\circ} \mathrm{W}$ (from the focal mechanism in Figure 2) upward from the centroid depth of $32 \mathrm{~km}$, it intersects the Earth's surface approximately at the major fault bounding the eastern side of the Malawi rift (Figure 5d). Thus the available evidence is consistent with this major fault zone extending to $\sim 30-\mathrm{km}$ depth and being responsible for the 1989 earthquake. We emphasize that in the absence of associated surface faulting and without a precisely determined hypocenter we cannot be certain that this hypothesis is correct, but it seems to us to be plausible. Nor can we distinguish between a seismogenic fault extending from the surface to $30 \mathrm{~km}$ and a fault zone that is seismogenic only in the upper crust and at $30 \mathrm{~km}$ but exists as a ductile shear zone in between. It could be argued that uncertainty in the epicenter also allows the earthquake to have occurred on a buried fault beneath the monocline, but the macroseismic epicenter is west of the expected epicenter if a fault in this position is projected to a depth of $30 \mathrm{~km}$ with a dip of $55^{\circ}$ corresponding to that of the nodal plane dipping east in Figure 2 [Gupta, 1992].

No surface faulting was reported from the 1989 earthquake [Gupta, 1992]. This is not surprising given the depth of the earthquake and its likely source dimensions. We can estimate the dimensions of the fault that slipped in the earthquake from the seismic moment $\left(M_{0}\right)$ of $1.8 \times 10^{18} \mathrm{~N} \mathrm{~m}$, since $M_{0}=\mu A \bar{u}$, where $\mu=3 \times 10^{10} \mathrm{~N} \mathrm{~m}^{-2}$ is the rigidity modulus, $A$ is the fault area, and $\bar{u}$ is the average slip. If we assume an approximately equidimensional fault surface of length and width, $L$, and also that $\bar{u} / L$ is $\sim 5 \times 10^{-5}$, which is typical 


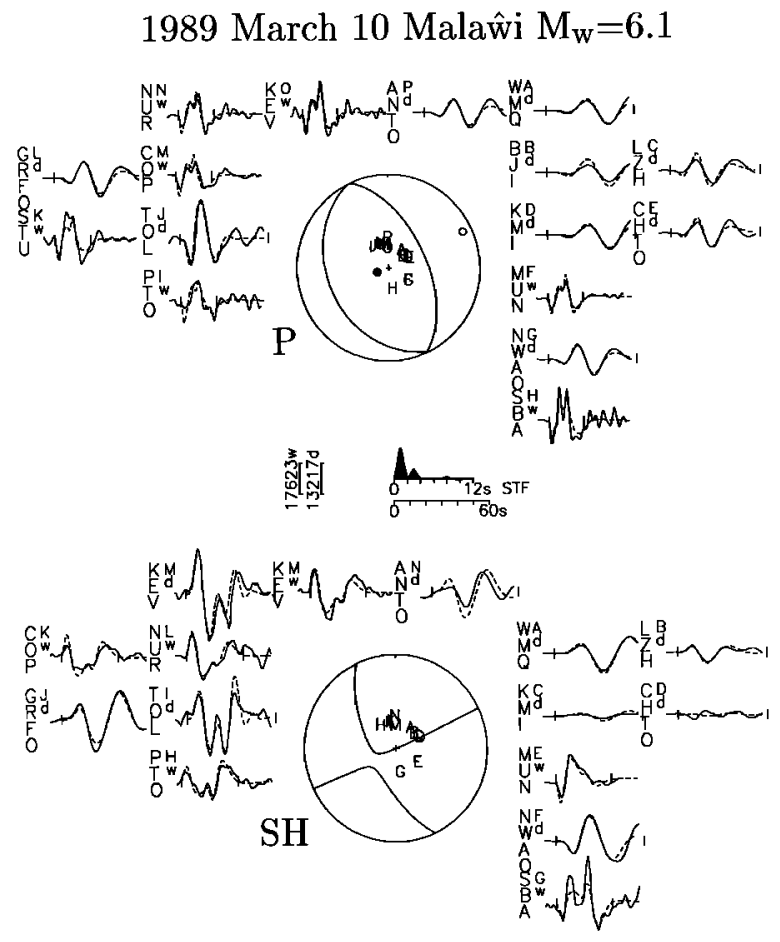

Fig. 2. Observed (solid) and synthetic (dashed) waveforms for the 1989 Malawi earthquake. Station positions on focal spheres are identified by capital letters, starting clockwise from north. STF is the source time function. The assumed source crustal structure was a layer $10 \mathrm{~km}$ thick with $\mathrm{V}_{p} 6.0 \mathrm{~km} \mathrm{~s}^{-1}$ above a half-space of $\mathrm{V}_{p} 6.8 \mathrm{~km} \mathrm{~s}^{-1}$. Source parameters are given in Table 2 .

for continental earthquakes [Scholz, 1982], then $L \approx 10 \mathrm{~km}$. This is also consistent with the 4 -s duration of the source time function, which suggests a fault length of $\sim 12 \mathrm{~km}$ for a typical rupture velocity of $3 \mathrm{~km} \mathrm{~s}^{-1}$, assuming a unilateral rupture. If rupture was bilateral (spreading out from the center of the fault plane), the time function would allow a larger fault. These are simplistic calculations but show that the source dimensions of the earthquake were smaller than the centroid depth.

The mainshock of March 10 was preceded by a foreshock of $m_{b} 5.8\left(M_{w} 5.7\right)$ on March 9 with virtually the same instrumentally determined epicenter as the mainshock. Fewer teleseismic waveforms are available for the foreshock than for the mainshock a day later, and these have a poor azimuthal distribution. Our attempts to analyze the long period $P$ and $S H$ waveforms of the foreshock were not satisfactory. The waveforms are consistent with the Harvard CMT solution (strike $128^{\circ}$, $\operatorname{dip} 23^{\circ}$, and rake $-118^{\circ}$ ) [Dziewonski et al., 1990], which is similar to that of the mainshock, and with the reported ISC depth of $30 \mathrm{~km}$. However, they do not allow the trade-off between the source time function and the centroid depth to be decreased to a useful level.

\section{OTHER POSSIBLE MANIFESTATIONS OF LITHOSPHERE STRENGTH}

We conclude that the strike, dip, location, and depth of the faulting in the March 10, 1989 earthquake are all consistent with slip at $\sim 30-\mathbf{k m}$ depth on part of a major west dipping fault zone bounding the east side of Lake Malawi, although we emphasize that this cannot be proved. We believe that such deeply penetrating faults could reasonably be expected in lithosphere that is colder and stronger than normal. Are there any other manifestations of such strength? There are three features of the rifting in east Africa that may be related to a stronger upper part of the lithosphere.

\section{Effective Elastıc Thrckness}

Several people [e.g., Bechtel et al., 1987; Ebinger et al., 1989a] have used the coherence between gravity anomalies and topography in east Africa to demonstrate that the effective elastic thickness $\left(T_{e}\right)$ of the east African lithosphere is as high as $20-40 \mathrm{~km}$, even within rifted areas. These high values of $T_{e}$ in east Africa, where rifting often cuts through metamorphic rocks of

Archean-Proterozoic age, contrast with much lower values (typically less than $10-15 \mathrm{~km}$ ) in rifted areas that have undergone Paleozoic or Mesozoic orogeny [e.g., Barton and Wood, 1984; Fowler and McKenzie, 1989; Bechtel et al., 1990]. We do not know whether all or part of this increase in effective elastic thickness is due to the increased strength of the mantle rather than that of the lower crust. Nor do we know whether the earthquakes at $\sim 30 \mathrm{~km}$ signify a seismogenic thickness of $30 \mathrm{~km}$ for the crust or simply localized seismic activity beneath an aseismic lower crust, so we cannot compare the thickness of the seismogenic crust with the effective elastic thickness (there is, in any case, no reason why they should have the same value). However, since both the maximum depth of earthquakes and the effective elastic thickness are probably related to thermal structure [e.g., Wiens and Stein, 1983], we might expect them both to increase or decrease together. We therefore attribute the anomalously high values for both in east Africa to the old, cold material in which the rifts are forming.

\section{Width of Half Graben}

A notable feature of some east African half graben (including those in the Malawi rift) is their width across

TABLE 2. Source Parameters Determined for the March 10, 1989, Earthquake in This Study versus Those of the Harvard Centroid Moment Tensor Solution

\begin{tabular}{lccccl} 
& Strike & Dip & Rake & Depth, km & Moment, N m \\
\hline This paper & $154 \pm 25$ & $34 \pm 5$ & $-92 \pm 25$ & $32 \pm 5$ & $1.9 \times 10^{18}$ \\
Harvard CMT & 142 & 17 & -102 & 15 & $3.1 \times 10^{18}$ \\
\hline
\end{tabular}


Final

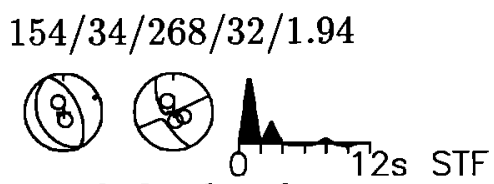

Depth fixed $25 \mathrm{~km}$

$144 / 37 / 264 / 25 / 2.60$
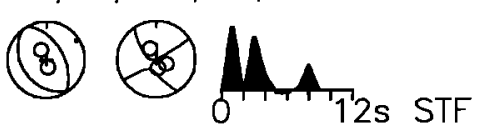

Depth fixed $10 \mathrm{~km}$

$143 / 41 / 263 / 10 / 4.62$
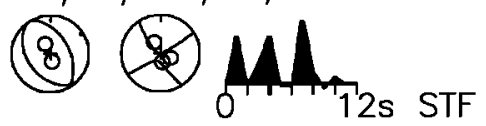

Harvard orientation fixed

$142 / 17 / 258 / 33 / 1.62$

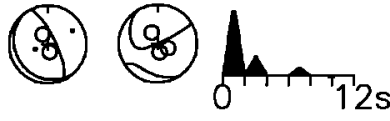

12s STF

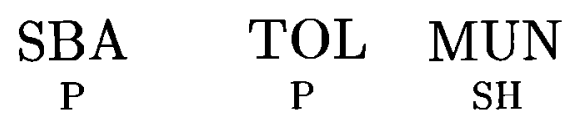

SBA

TOL

$\mathrm{SH}$

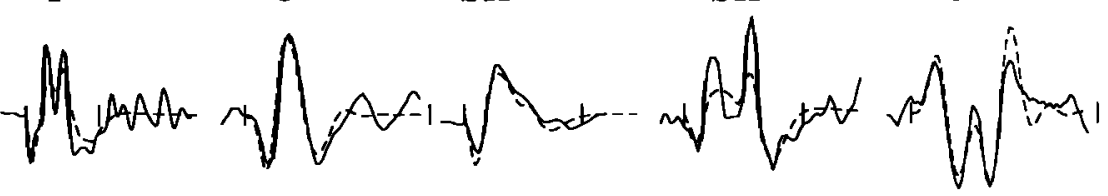

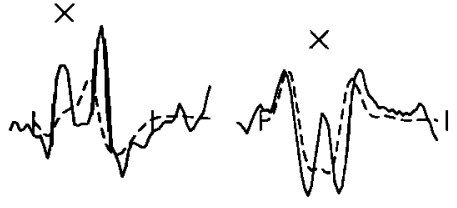

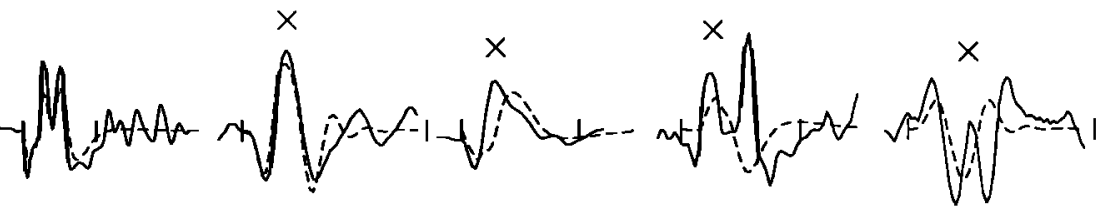

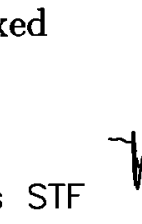
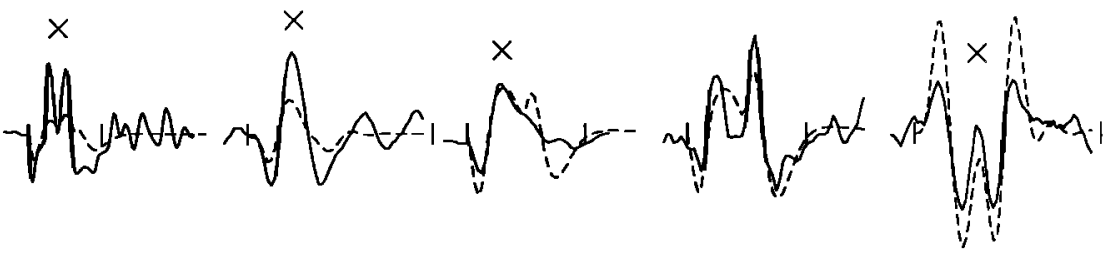

Fig. 3. Examples of tests to resolve source parameters. The top row shows selected $P$ and $S H$ waveforms for the final inversion result. The numbers above the focal spheres are, in order, the strike, dip, rake, depth (kilometers), and $M_{0}\left(\times 10^{18} \mathrm{~N} \mathrm{~m}\right)$. Parameters in bold numbers were fixed during the inversion. The waveforms in the second row are at the same stations for an inversion where the depth is fixed at $25 \mathrm{~km}$ but other parameters are free. Those marked with crosses have an inferior match between observed and synthetic waveforms compared to the waveforms in the first row. The third row is for a fixed depth of $10 \mathrm{~km}$. The fourth row is for an inversion in which the strike, dip, and rake are fixed to values of the Harvard CMT solution, but the other parameters are left free.

strike, which may be $40-50 \mathrm{~km}$ or more (Figure 5) [Rosendahl et al., 1986; Specht and Rosendahl, 1989; Ebinger, 1989; Flannery and Rosendahl, 1990]. Such widths are much larger than the maximum of about $25 \mathrm{~km}$ that is typical elsewhere on the continents [see Jackson and White, 1989]. All topography and lateral density contrasts are maintained by shear stresses, which in half graben are concentrated near faults. These shear stresses increase with the width of the half graben and, for a given width, decrease as effective elastic thickness of the lithosphere increases [McKenzie, 1967; Jackson and White, 1989]. Wide half graben require smaller shear stresses to support them if they form in thick elastic sheets rather than in thin ones. Jackson and White [1989] speculated that the maximum width of continental half graben is controlled by the effective elastic thickness and the maximum shear strength of faults: for a maximum shear strength on faults of $\sim 10 \mathrm{MPa}$ (100 bars) and an elastic thickness of $\sim 15 \mathrm{~km}$, half graben up to $\sim 25 \mathrm{~km}$ in width are to be expected. A rough estimate of the necessary stresses can be obtained from the expressions of Jackson and White [1989]. Consider a half graben similar to that on the profiles in Figure $5 \mathrm{a}$ with a width of $40 \mathrm{~km}$ and a vertical amplitude (depth) of $3 \mathrm{~km}$ in basement of density $2.85 \mathrm{Mg} \mathrm{m}^{-s}$ but filled to a depth of $2.5 \mathrm{~km}$ with sediment of density $2.0 \mathrm{Mg} \mathrm{m}^{-3}$. For an elastic thickness of $10 \mathrm{~km}$ the maximum shear stresses required are $\sim 18.6 \mathrm{MPa}$ (186 bars). For an elastic thickness of $30 \mathrm{~km}$, closer to that estimated at the northern end of the Malawi rift by Ebinger et al. [1991], the maximum required shear stresses reduce to $\sim 5.6 \mathrm{MPa}$. This lower value of stress is comparable with typical stress drops in continental earthquakes (usually in the range 1-10 MPa [e.g., Scholz, 1982]). We can estimate the stress drop in the 1989 earthquake as follows: if we take $L=12 \mathrm{~km}$ from the duration of the source time function, then from the seismic moment, $\bar{u} \approx 0.4 \mathrm{~m}$, and the stress drop, which is approximately $\mu \bar{u} / L$, is $\sim 0.8 \mathrm{MPa}(8$ bars). The calculations in this paragraph are all approximate, but they illustrate the important point that the wide half graben can be maintained dynamically without requiring shear stresses on the faults that are significantly greater than the stress drops typically seen in earthquakes, particularly if the elastic thickness is as large as other authors suggest.

There is no reason why the stress drop in earthquakes should necessarily equal the total shear stress on faults. Our inference that the topography does not require 

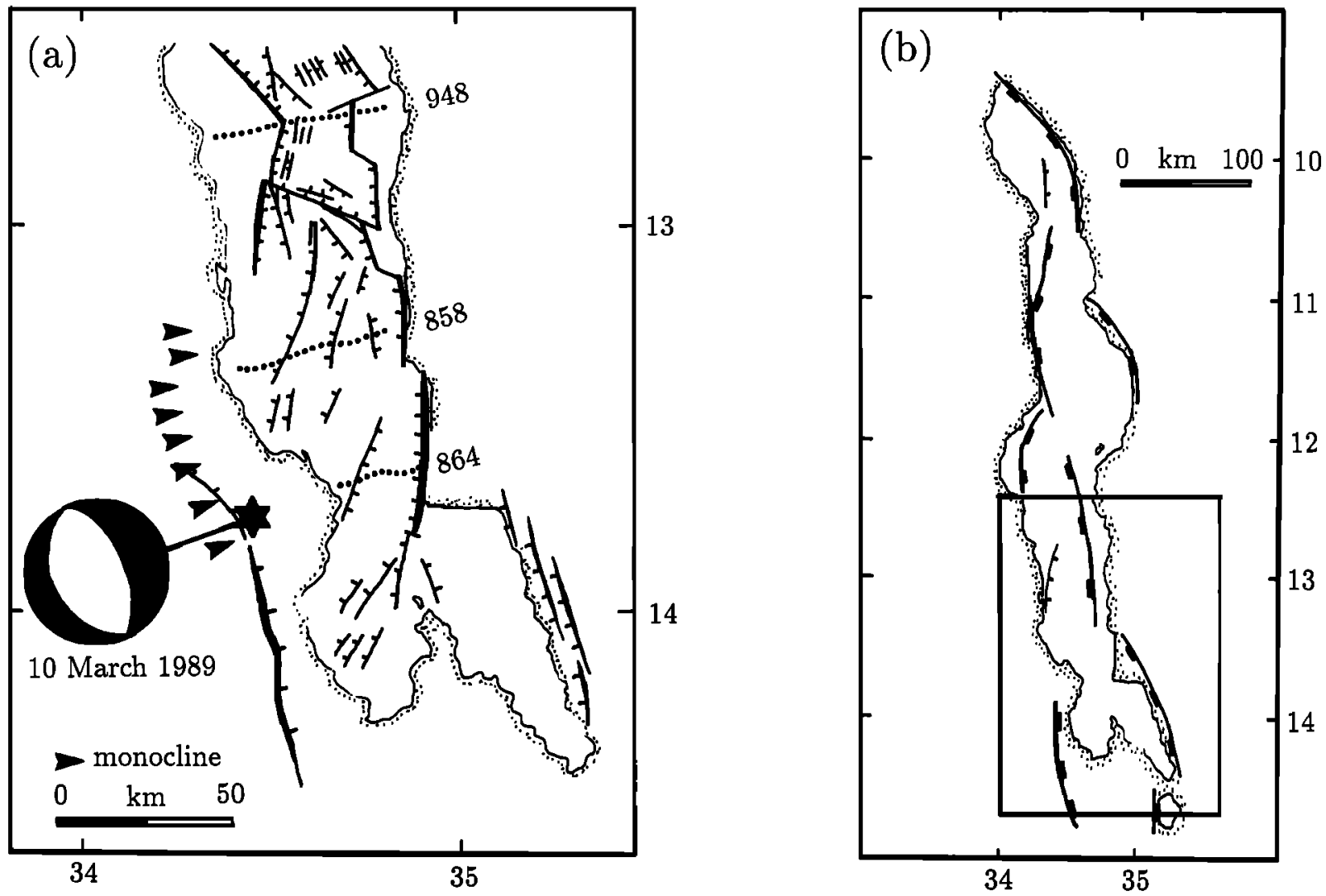

Fig. 4. (a) Tectonic map of the Bouthern part of Lake Malawi, based on Ebinger et al. [1987] and Scholz [1987]. The large star is the epicenter of the March 10, 1989 earthquake. The positions of seismic reflection profiles 948 and 858 from Flannery and Rosendahl [1990] and 864 from Specht and Rosendahl [1989] are shown as dotted lines. (b) Summary map of Lake Malawi, based on Specht and Rosendahl [1989], showing (schematically) the polarity of the major fault systems bounding the rift. The inset shows the region in Figure $4 \mathrm{a}$.

stresses much greater than those released in earthquakes is, however, consistent with the growing view that major continental faults are weak zones in the crust [e.g., Sleep and Blandpied, 1992; Rice, 1992] and that the stress drops in large earthquakes are close to the total shear stress on faults. Thus the wider half graben in east Africa may simply be a consequence of the greater elastic thickness, which can support structures of such width without requiring the shear stresses on the faults to increase beyond those that are typical elsewhere.

\section{Fault Segment Lengths}

The fault systems bounding continental rifts are commonly segmented, stepping en echelon or changing the polarity of half graben along strike [e.g., Rosendahl et al., 1986; Crone and Haller, 1991; Roberts and Jackson, 1991]. This segmentation potentially limits the extent of rupture and hence the size of earthquakes [e.g., Schwartz and Sibson, 1989]. Jackson and White [1989] and Wallace [1989] point out the similarity between the maximum segment length of $\sim 20-25 \mathrm{~km}$ common in many rifts and the usual thickness (or downdip fault width) of the seismogenic upper crust. They suggest that the thickness of the relatively strong upper part of the lithosphere, which they associate with the thickness of the seismogenic crust, in some way influences the lateral continuity of the normal faults that form within it. In most regions of continental extension the thickness of the seismogenic layer varies little from 10 to $15 \mathrm{~km}$, and so this hypothesis is untestable, as these places are all likely to have a strong upper layer of comparable thickness. However, we have argued above that the presence of deeper earthquakes in east Africa suggests that the upper part of the lithosphere is colder and hence stronger to greater depths than elsewhere. We can reasonably ask: Are the fault segments within this thicker, stronger upper layer longer than elsewhere?

Individual half graben longer than $100 \mathrm{~km}$ are common in east Africa [see Rosendahl et al., 1986; Specht and Rosendahl, 1989], but whether the faults bounding them are continuous or step en echelon is not clear. Some are certainly segmented at a scale much smaller than $100 \mathrm{~km}$, but segment lengths of up to $50 \mathrm{~km}$ are common in several detailed studies of fault structure and geomorphology [Crossley, 1984; Ebinger et al., 1989b; Wheeler and 

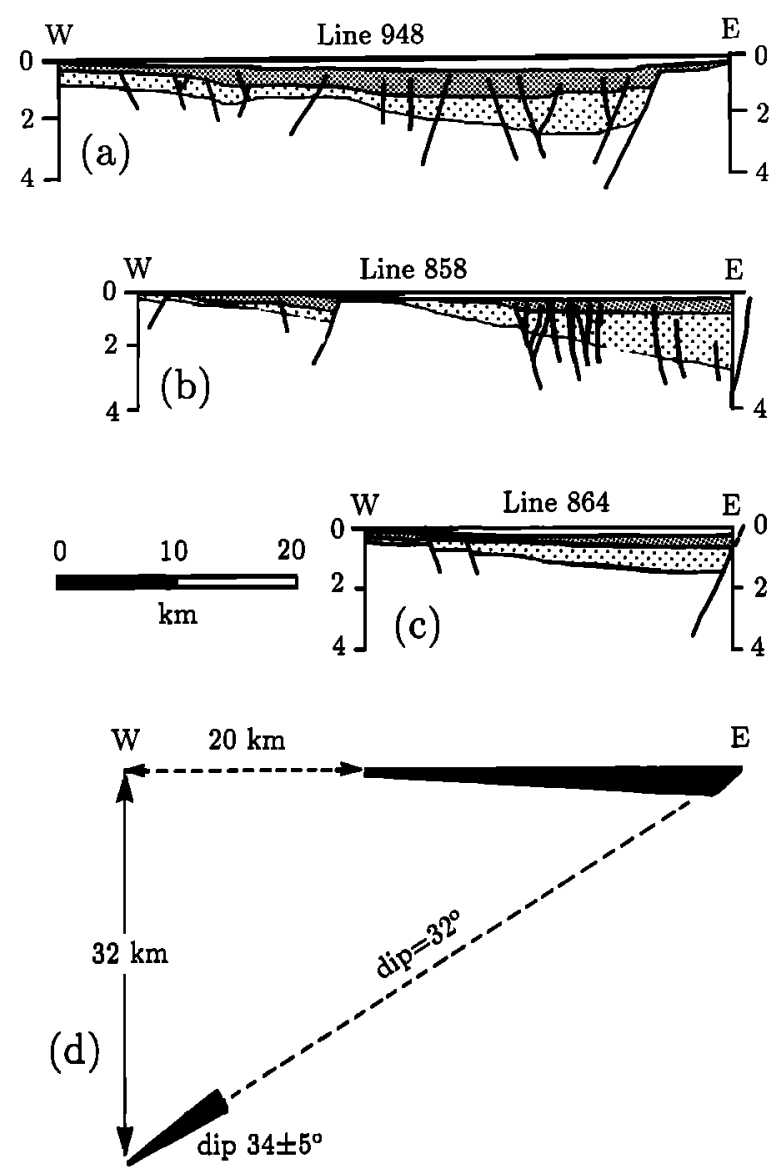

Fig. 5. (a)-(c) Interpreted cross sections from Flannery and Rosendahl [1990] and Specht and Rosendahl [1989] along the lines shown in Figure 4, vertically exaggerated by $x \sim 3$. Shading identifies distinguishable seismic sequences. The vertical scale is in seconds, two-way travel time. (d) The projected depth and dip of the inferred fault plane of the 1989 earthquake shown on profile 864 with no vertical exaggeration. A line joining the inferred hypocenter to the surface outcrop of the fault bounding the half graben dips at $32^{\circ}$, which is within the dip range of $34 \pm 5^{\circ}$ estimated for the west dipping nodal plane in the earthquake.

Karson, 1989; Kilembe and Rosendahl, 1992]. We conclude that these long fault segments may well be a consequence of the thicker, stronger upper part of the deforming east African lithosphere.

These relatively long segment lengths have implications for seismic risk in east Africa, as they have the potential for generating earthquakes of $M_{w} 7.2$ or greater. The largest known normal faulting earthquakes in the region are the $M_{0} 6.9$ earthquake of 1928 in Kenya, which moved an apparently continuous fault segment at least $38 \mathrm{~km}$ long [Ambraseys, 1991a], and the $M_{w} 7.1$ earthquake of May 24, 1990 in Sudan (Table 1), about which no field information is known. The 1910 Rukwa earthquake was larger still $\left(M_{g} \sim 7.4\right)$, but there is no clear evidence that it involved normal faulting [Ambraseys, 1991b].

\section{DISCUSSION}

The east African rift system, often regarded as the archetype of continental rifts, is unusual in several respects: it has deeper earthquakes, wider half graben, greater effective elastic thickness, and probably longer fault segment lengths (and thus potentially larger normal faulting earthquakes) than are common in other regions of continental extension. The purpose of this paper is to point out that these observations may all be connected and related to the probability that the upper lithosphere is colder (and hence is strong to greater depths) than is typical elsewhere. The significance of the 1989 Malawi earthquake is that its location, mechanism, and depth are all consistent with slip on a fault zone that does indeed extend throughout the upper $30 \mathrm{~km}$ of crust, even though we do not know whether it exists as a seismogenic fault throughout this depth range. It is the first of the unusually deep earthquakes in east Africa that can plausibly be related to a structure at the surface, although it involved slip on only a part of the postulated fault zone at depth. The Malawi rift system is relatively young and little extended and is forming in old, cold lithosphere [Bloomfield, 1968; Crossley and Crow, 1980; Versfelt and Rosendahl, 1989]. We expect that the reason most of the deeper earthquakes in east Africa are outside the most extended part of the late Cenozoic rift system is that the thermal structure in their epicentral regions is still relatively shieldlike and cold (see also Shudofsky et al. [1987]). In all these anomalous respects, the east African rift system may have similarities with the Lake Baikal rift system, which may also have a large elastic thickness [Diament and Kogan, 1990] and earthquakes as deep as $\sim 40 \mathrm{~km}$ [Déverchère et al., 1991].

\section{CONCLUSIONS}

The purpose of this paper was to point out that the deeper earthquakes, greater effective elastic thickness, wider half graben, and longer normal fault segments that characterize parts of the east African rift system relative to rifts elsewhere may all be connected. We suggest that they are all related to the old, cold lithosphere in which parts of the east African rift system are forming and that they are consistent with earlier suggestions [e.g., Weissel and Karner, 1989] that under some circumstances, normal faulting and significant strength exist throughout the bulk of the crustal thickness during rifting. With the available data we are unable to say whether the deeper earthquakes have centroids in the lowermost crust or uppermost mantle, nor do we know whether seismogenic faulting is continuous from those depths to the surface. For the purpose of this paper that uncertainty does not matter: the very fact that such deeper earthquakes occur at all suggests to us that the strong upper layer of the lithosphere is thicker than normal, and the association of the deep earthquakes with unusually wide half graben and unusually long fault segments is consistent with the suggestion that the thickness of this strong upper layer is the main factor influencing the scale of the geological structures that form within it. 
Acknowledgements. We appreciate generous and helpful reviews from C. Ebinger, G. Karner, D. McKenzie, P. Maguire, N. White, G. Yielding, and an anonymous reviewer, all of whom improved this paper. However, the views expressed are our own, and we alone are responsible for any remaining errors and misconceptions. We thank Shell, Amerada Hess, and N.E.R.C. for support of this work. Cambridge Earth Sciences contribution 3315.

\section{REFERENCES}

Ambraseys, N.N., Earthquake hazard in the Kenya rift: The Subukia earthquake 1928, Geophys. J. Int., 105, 253-269, 1991 a.

Ambraseys, N.N., The Rukwa earthquake of 13 December 1910 in east Africa, Terra Motae, 9, 202-211, 1991b.

Barton, P.J., and R. Wood, Tectonic evolution of the North Sea basin: Crustal stretching and subsidence, Geophys. J. R. Astron. Soc., 79, 987-1002, 1984.

Bechtel, T.D., D.W. Forsyth, and C.J. Swain, Mechanisms of isostatic compensation in the vicinity of the east African rift, Kenya, Geophys. $J$. R. Astron. Soc., 90, 445-465, 1987.

Bechtel, T.D., D.W. Forsyth, V.L. Sharpton, and R.A.F. Grieve, Variations in effective elastic thickness of the North American lithosphere, Nature, 343, 636-638, 1990.

Bloomfield, K., The pre-Karoo geology of Mala ŵi, Mem. Geol. Surv. Malaŵi, 5, 1-166, 1968.

Brace, W.F., and D. Kohlstedt, Limits on lithospheric stress imposed by laboratory measurements, J. Geophys. Res., 85, 6248-6252, 1980.

Braunmiller, J., and J. Nábĕlek, The 1989 Ethiopia earthquake sequence (abstract), Eos, Trans. AGU, 71, 1480, 1990.

Chapola, L.S., and C.E. Kaphwiyo, The Malawi rift: Geology, tectonics and seismicity, Tectonophysıcs, 209, 159-164, 1992.

Chen, W-P., and P. Molnar, Focal depths of intracontinental and intraplate earthquakes and their implications for the thermal and mechanical properties of the lithosphere, J. Geophys. Res., 88, 4183-4214, 1983.

Crone, A.J., and K.M. Haller, Segmentation and coseismic behaviour of basin-and-range normal faults: Examples from east-central Idaho and southwestern Montana, U.S.A., $J$. Struct. Geol., 13, 151-164, 1991.

Crossley, R., Controls of sedimentation in the Malawi rift valley, central Africa, Sediment. Geol., 40, 33-50, 1984.

Crossley, R., and M.J. Crow, The Malawi rift, in Geodynamic Evolution of the Afro-Arabian Raft System, pp. 77-87, Accademia Nazionale dei Lincei, Rome, 1980.

Déverchère, J., F. Houdry, M. Diament, N.V. Solonenko, and A.V. Solonenko, Evidence for a seismogenic upper mantle and lower crust in the Baikal rift, Geophys. Res. Lett., 18, 1099-1102, 1991.

Diament, M., and M.G. Kogan, Long wavelength gravity anomalies and the deep thermal structure of the Baikal rift, Geophys. Res. Lett., 17, 1977-1980, 1990.

Dziewonski, A., G. Ekstrōm, J. Woodhouse, and G. Zwart, Centroid moment tensor solutions for January-March 1989, Phys. Earth Planet. Inter., 59, 233-242, 1990.

Ebinger, C.J., Tectonic development of the western branch of the east African rift system, Geol. Soc. Am. Bull., 101, 885-903, 1989.

Ebinger, C.J., M.J. Crow, B.R. Rosendahl, D.A. Livingstone, and J. LeFournier, Structural evolution of Lake Malawii, Africa, Nature, 308 , 627-629, 1984.

Ebinger, C.J., B.R. Rosendahl, and D.J. Reynolds, Tectonic model of the Malawii rift, Africa, Tectonophysics, 141, 215-235, 1987.

Ebinger, C.J, T.D. Bechtel, D.W. Forsyth, and C.O. Bowin, Effective elastic plate thickness beneath the East African and Afar plateaus and dynamic compensation of the uplifts, J. Geophys. Res., 94, 2883-2901, 1989a.

Ebinger, C.J., A. Deino, R. Drake, and A.L. Tesha, Chronology of volcanism and rift propagation: Rungwe volcanic province, Africa, J. Geophys. Res., 94, 15,785-15,803, 1989b.

Ebinger, C.J., G.D. Karner, and J.K. Weissel, Mechanical strength of extended continental lithosphere: Constraints from the western rift system, east Africa, Tectonics, 10 , 1239-1256, 1991.

Flannery, J.W., and B.R. Rosendahl, The seismic stratigraphy of Lake Malawî, Africa: Implications for interpreting geological processes in lacustrine rifts, J. Afr. Earth Sci., 10, 519-548, 1990.

Fowler, S., and D. McKenzie, Flexural studies of the Exmouth and Rockal plateaux using SEASAT altimetry, Basin Res., 2, 27-34, 1989.

Gaulon, R., J. Chorowicz, G. Vidal, B. Romanowicz, and G. Roult, Regional geodynamic implications of the May-July 1990 earthquake sequence in southern Sudan, Tectonophysics, 209, 87-103, 1992.

Grimison, N.L., and W-P. Chen,
Earthquakes in the Davie

Ridge-Madagascar region and the southern Nubian-Somalian plate boundary, J. Geophys. Res., 99, 10,439-10,450, 1988.

Gupta, H.K., The Malawi earthquake of March 10, 1989: A report of a macroseismic survey, Tectonophysics, 209, 165-166, 1992.

Jackson, J.A., and N.J. White, Normal faulting in the upper continental crust: Observations from regions of active extension, J. Struct. Geol., 11, 15-36, 1989.

Kebede, F., W-Y. Kim, and O. Kulhánek, Dynamic source parameters of the March-May 1969 Serdo earthquake sequence in central Afar, Ethiopia, deduced from teleseismic body waves, J. Geophys. Res., 94, 5603-5614, 1989.

Kilembe, E.A., and B.R. Rosendahl, Structure and stratigraphy of the Rukwa rift, Tectonophysics, 209, 143-158, 1992.

McCaffrey, R., and G. Abers, SYN3: A program for inversion of teleseismic body wave forms on microcomputers, Tech. Rep. AFGL-TR-88-0099, Air Force Geophys. Lab., Hanscomb Air Force Base, Mass., 1988.

McCaffrey, R., and J. Nábèlek, Earthquakes, gravity and the origin of the Bali basin: An example of a nascent continental fold-and-thrust belt, J. Geophys. Res., 92, 441-460, 1987.

McKenzie, D., Some remarks on heat flow and gravity anomalies, $J$. Geophys. Res., 72, 6261-6273, 1967.

Nábélek, J.L., Determination of earthquake source parameters from inversion of body waves, Ph.D. thesis, Mass. Inst. of Technol., Cambridge, Mass., 1984.

Nyblade, A.A., K.P. Furlong, and C.A. Langston, Deep crustal earthquakes in Africa (abstract), Eos, Trans. AGU, 79(43), Fall Meeting suppl., 345, 1992.

Rice, J.R., Fault stress states, pore pressure distributions, and the weakness of the San Andreas fault, in Fault Mechanics and Transport Properties of Rocks, edited by B. Evans, and T-F. Wong, pp. 475-503, Academic, San Diego, Calif., 1992.

Roberts, S., and J.A. Jackson, Active normal faulting in central Greece: An overview, in The Geometry of Normal Faults, edited by A.M. Roberts, G. 
Yielding, and B. Freeman, Geol. Soc. Spec. Publ. London, 56, 125-142, 1991. Rosendahl, B.R., D.J. Reynolds, P.M. Lorber, C.F. Burgess, J. McGill, D. Scott, J.J. Lambiase, and S.J. Derksen, Structural expressions of rifting: Lessons from Lake Tanganyika, Africa, in Sedimentation in the African Rifts, edited by L.E. Frostick, R.W. Renaut, I. Reid, and J.J. Tiercelin, Geol. Soc. Spec. Publ. London, 25, 29-43, 1986.

Scholz, C.A. (Ed.), Project PROBE Geophysical Atlas Series, vol. 2, Duke University, Durham, N.C., 1987.

Scholz, C.H., Scaling laws for large earthquakes: Consequences for physical models, Bull. Seismol. Soc. A m., 72, 1-14, 1982.

Scholz, C.H., The brittle-plastic transition and the depth of seismic faulting, Geol. Rundsch., 77, 319-328, 1988.

Schwartz, D.P., and R.H. Sibson, Fault segmentation and controls of rupture initiation and termination, U.S. Geol. Surv. Open File Rep. 89-315, 447, 1989.

Shudofsky, G.N., Source mechanisms and focal depths of East African earthquakes using Rayleigh wave inversion and body wave modelling, Geophys. J. R. Astron. Soc., 89, 563-614, 1985.

Shudofsky, G.N., S. Cloetingh, S. Stein, and R. Wortel, Unusually deep earthquakes in east Africa: Constraints on the thermo-mechanical structure of a continental rift system, Geophys. Res. Lett., 14, 741-744, 1987.

Sleep, N.H., and M.L. Blandpied, Creep, compaction and the weak rheology of major faults, Nature, 359, 687-692, 1992.

Specht, T.D., and B.R. Rosendahl, Architecture of the Lake Malawii rift, east Africa, J. Afr. Earth Sci., 8 , 355-382, 1989.

Taymaz, T., J. Jackson, and D. McKenzie, Active tectonics of the north and central Aegean Sea, Geophys. J. Int., 106, 433-490, 1991.

Versfelt, J., and B.R. Rosendahl, Relationships between pre-rift structure and rift architecture in Lakes Tanganyika and Malawii, east Africa, Nature, 397, 354-356, 1989.

Wagner, G.S., and C.A. Langston, East African body wave inversion with implications for continental structure and deformation, Geophys. J., Oxford, 94, 503-518, 1988.

Wagner, G.S., and C.A. Langston, Some pitfalls and trade-offs in source parameter determination using body wave modelling and inversion, Tectonophysics, 166, 101-114, 1989.

Wallace, R.E., Fault plane segmentation in brittle crust and anisotropy in loading system, in Fault Segmentation and Controls of Rupture Initiation and Termination, edited by D.P. Schwartz and R.H. Sibson, U.S. Geol. Surv.
Open File Rep., 89-315, 400-408, 1989. Weissel, J.K., and G.D. Karner, Flexural uplift of rift flanks due to mechanical unloading of the lithosphere during extension, J. Geophys. Res., 94, 13,919-13,950, 1989.

Wheeler, W.H., and J.A. Karson, Structure and kinematics of the Livingstone Mountains border fault zone, Nyasa (Malâ̂i) rift, southwestern Tanzania, J. Afr. Earth Sci., 8, 393-413, 1989.

Wiens, D.A., and S. Stein, Age dependence of oceanic intraplate seismicity and implications for lithospheric evolution, J. Geophys. Res., 88, 6455-6468, 1983.

Yarwood, D.R., and D.I. Doser, A re-examination of the May 7, 1964 earthquake, a deep event in northern Tanzania (abstract), Eos, Trans. $A G U$, $69,1312,1988$.

T. Blenkinsop, Department of Geology, University of Zimbabwe, P.O. Box MP 167, Mount Pleasant, Harare, Zimbabwe. J. Jackson, Bullard Laboratories, Cambridge University, Madingley Road, Cambridge, CB3 0EZ, England.

(received October 14, 1992; revised March 19, 1993; accepted April 15, 1993.) 